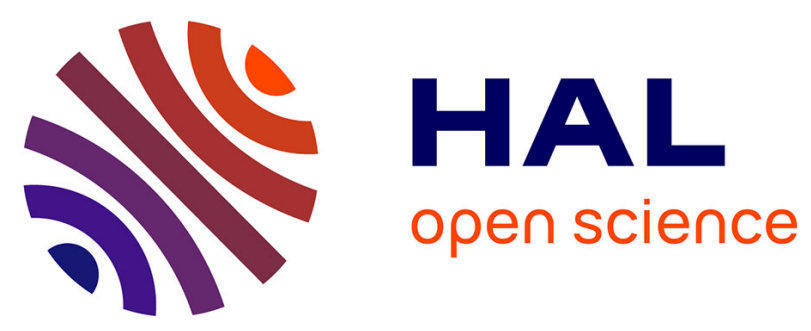

\title{
Response to Letter to the Editor, "The Role of Membrane Attack Complex Formation against Gram-positive Bacteria"
}

Charlotte Jeanneau, Imad About

\section{- To cite this version:}

Charlotte Jeanneau, Imad About. Response to Letter to the Editor, "The Role of Membrane Attack Complex Formation against Gram-positive Bacteria". Journal of Dental Research, 2016, 95 (4), pp.477. 10.1177/0022034515626676 . hal-01458936

\section{HAL Id: hal-01458936 https://hal-amu.archives-ouvertes.fr/hal-01458936}

Submitted on 28 Jan 2022

HAL is a multi-disciplinary open access archive for the deposit and dissemination of scientific research documents, whether they are published or not. The documents may come from teaching and research institutions in France or abroad, or from public or private research centers.
L'archive ouverte pluridisciplinaire $\mathbf{H A L}$, est destinée au dépôt et à la diffusion de documents scientifiques de niveau recherche, publiés ou non, émanant des établissements d'enseignement et de recherche français ou étrangers, des laboratoires publics ou privés. 


\title{
Response to Letter to the Editor, "The Role of Membrane Attack Complex Formation against Gram-positive Bacteria”
}

\author{
C. Jeanneau' and I. About'
}

It has long been accepted that Gram-positive bacteria resist the membrane attack complex (MAC) because of a protective, thick peptidoglycan layer (Joiner et al. 1983). However, this is contradicted by reports showing that MAC components are assembled on Gram-positive bacteria in specific localizations and that this assembly differs among bacterial strains (Berends et al. 2013). Also, MAC components' deficiency increases patients' susceptibility to infections not only with Gramnegative but also with some Gram-positive bacteria (Skattum et al. 2011). Moreover, many Gram-positive bacteria not only recruit the host inhibitors of MAC but also express proteins that inhibit MAC formation (Laursen et al. 2010). For example, Streptococcus pyogenes secretes streptococcal inhibitor of complement, which blocks the C5b-7 membrane insertion site and thereby prevents MAC formation (Akesson et al. 1996). This shows clearly that the peptidoglycan wall is not enough to protect all Gram-positive bacteria from MAC lysis.

During carious decay, the pulp is subject to invasion mainly by Gram-positive bacteria. This specialized tissue has a terminal circulation, and it has been shown that, in addition to the systemic regulation, the pulp plays a role in its own local regulation of innervation, vascularization, and regeneration (About 2013). Also, it appears unique with regard to complement synthesis and function (Chmilewsky et al. 2014).

Thus, we share the enthusiasm of Alves and Freires (2016) in their letter to the editor regarding our recently published work (Jeanneau et al. 2015). Indeed, these new data pave the way for future research on pulp synthesis of MAC co-stimulators/ inducers and the way that this affects Gram-positive bacteria.

\section{Acknowledgments}

The work discussed was supported by institutional funding from Aix Marseille Université and Centre National de la Recherche
Scientifique. The authors declare no potential conflicts of interest with respect to the authorship and/or publication of this article.

\section{References}

About I. 2013. Dentin-pulp regeneration: the primordial role of the microenvironment and its modification by traumatic injuries and bioactive materials. Endod Top. 28(1):61-89.

Akesson P, Sjöholm AG, Björck L. 1996. Protein SIC, a novel extracellular protein of Streptococcus pyogenes interfering with complement function. J Biol Chem. 271(2):1081-1088.

Alves LA, Freires IA. 2016. Letter to the editor, "the role of membrane attack complex formation against Gram-positive bacteria.” J Dent Res. 95(4):476.

Berends ET, Dekkers JF, Nijland R, Kuipers A, Soppe JA, van Strijp JA, Rooijakkers SH. 2013. Distinct localization of the complement C5b-9 complex on Gram-positive bacteria. Cell Microbiol. 15(12):1955-1968.

Chmilewsky F, Jeanneau C, Laurent P, About I. 2014. Pulp fibroblasts synthesize functional complement proteins involved in initiating dentin-pulp regeneration. Am J Pathol. 184(7):1991-2000.

Jeanneau C, Rufas P, Rombouts C, Giraud T, Dejou J, About I. 2015. Can pulp fibroblasts kill cariogenic bacteria? Role of complement activation. J Dent Res. 94(12):1765-1772.

Joiner K, Brown E, Hammer C, Warren K, Frank M. 1983. Studies on the mechanism of bacterial resistance to complement-mediated killing, III: C5b-9 deposits stably on rough and type $7 \mathrm{~S}$. pneumoniae without causing bacterial killing. J Immunol. 130(2):845-849.

Laursen NS, Gordon N, Hermans S, Lorenz N, Jackson N, Wines B, Spillner E, Christensen JB, Jensen M, Fredslund F, et al. 2010. Structural basis for inhibition of complement C5 by the SSL 7 protein from Staphylococcus aureus. Proc Natl Acad Sci U S A. 107(8):3681-3686.

Skattum L, van Deuren M, van der Poll T, Truedsson L. 2011. Complement deficiency states and associated infections. Mol Immunol. 48(14):16431655 .

'Aix Marseille Université, Marseille, France

Corresponding Author:

I. About, Faculté d'Odontologie, Aix Marseille Université, 27 Boulevard Jean Moulin, I3385 Marseille, France.

Email: imad.about@univ-amu.fr 